\title{
Pengembangan Cara Berpikir Aljabar pada Tingkat Sekolah Dasar dengan Teori APOS
}

\author{
Fatizanolo Buulolo $^{1}$, Ichsan Zein Dalimunthe ${ }^{2}$, Yulan Indiana Sianipar ${ }^{3}$ \\ Medan State University \\ Email : yulanindiana97@gmail.com
}

\begin{abstract}
APOS dalam penelitian [3] ialah melihat bagaimana perspektif/pandangan yagn menggunakan konsep matematika. Perlu diketahui bahwa bagaimana pandangan siswa dalam sebuah hal teoritikal dapat menunjukkan bagaimana siswa tersebut memandang sebuah konsep matematika yang ada (apakah konsep tersebut berdasarkan konsep matematika yang ada atau berdasarkan konsep mereka sendiri). [3] Menjelaskan lebih lanjut bahwa action dapat menjadi sebuah process melalui pembentukan (konstruksi) mental yang disebut dengan interiorisasi (interiorization). Kemudian, seorang siswa dapat memprediksi hasil dari process tersebut tanpa harus melakukan hal itu. Siswa yang mempunyai konsepsi objektif (object) terhadap permasalahan matematis dapat menggambarkannya secara keseluruhan dan dapat menuju ke tingkat yang lebih tinggi. Schemas merupakan koordinasi dari ketiga hal sebelumnya (action,processes, dan object). Berdasarkan penelitian Dubinsky bahwa ada tiga hal lainnya yang berhubungan dengan APOS, yaitu analisis teoritikal (theoretical analysis), pengimplementasian intsruksi (design and implementation of instruction), dan evaluasi terhadap intsruksi (observation and evaluation of the implemented instruction). Analisis teoritikal, bahwa siswa dapat mengkonstruksikan/membangun sebuah pemahaman dari sebuah konsep yang ada. Kegiatan intruksi, hal ini dimaksudkan untuk menggambarkan secara jelas sebuah hal yang dapat membantu siswa dalam membangun analisis yang sudah mereka lakukan (dapat dengan bantuan komputer).
\end{abstract}

\section{A. Pendahuluan}

Memahami konsep dasar aljabar merupakan hal yang penting karena dengan pengetahuan dasar tersebut siswa mampu menghadapi permasalahan-permasalahan yang 
berkaitan dengan aljabar. Semua ruang lingkup dalam mateamtika, menggunakan aljabar sebagai alat dalam penyelesaian permasalahan. [5] menyatakan bahwa aljabar merupakan sebuah langkah awal dalam menyelesaikan sebuah permasalahan yang kompleks. Konsep dasar dalam aljabar ialah dapat menggambarkan sebuah permaslahan yang ada dan membangun sebuah rumus/formula yang berhubungan dengan permasalahan tersebut. Pembuktian (proofing) juga menjadi faktor penting dalam formula yang sudah kita bentuk tersebut, dengan begitu ketika kita menjumpai permasalahan yang sama kita tidak akan merasa keseulitan.

\section{B. Kajian Pustaka}

Keiran (2004) menjelaskan bahwa seseorang dapat berpikir secara aljabar ialah : generational skill, transformational skill, and global meta-level skill. Generational skill, merupakan keterampilan dalam merepresentasikan permasalahan yang ada ke dalam bentuk aljabar dan persamaan matematika. Transformational skill, keterampilan dalam mengoperasikan rumusan aljabar yang sudah ada kedalam bentuk yang lebih sederhana. Global meta-level skill, keterampilan yang dapat menghubungkan permasalahan yang sudah ada dengan permasahan umum lainnya yang berkaitan dengan permasalahan yang sedang di teliti.

Kebanyakan siswa pada sekolah dasar mengalami kesulitan dalam mempelajari aljabar, kesulitan tersebut disebabkan kurang mampunya mahasiswa dalam berpikir secara aljabar. [9] Menjelaskan bahwa kemampuan yang diperlukan dalam berpikir secara aljabar ialah kemampuan dalam menjelaskan hubungan dan prosedur penyelesaian, dan teknik umum yang dapat digunakan dalam menyelesaikan permasalahan aljabar.

\section{Pembuktian (Proofing)}

Berdasarkan [3] dijelaskan bahwa pembuktian dalam matematika merupakan sebuah hal penting, karena dalam menjelaskan sebuah pembuktian (proof) dari sebuah permasalahan matematika yang ada dapat membawa kita dalam pemahaman yang lebih mendalam serta membantu kita dalam berpikir. Pembuktian (proofing) ini juga dapat memberikan kita sebuah cara dalam mempelajari dan juga memberikan alasan (reasoning) dalam sebuah permasalahn matematika, serta dapat memberikan bantuan kepada tenaga didik dalam menyampaikan teorema-teorema matematika yang sudah ada. [3] Kebanyakan siswa dari tingkat dasar hingga ke tingkat universitas tidak dapat membuktikan 
sebuah teorema yang ada. [7] menemukan adanya tujuh kesulitan utama siswa dalam membuktikan (proofing), termasuk ketidakmampuan siswa dalam mendefinisikan sesuatu, tidak mampu menggambarkan sebuah konsep, ketidakmampuan mendefinisikan sebuah teorema yang ada, ketidakmampuan dalam memberikan sebuah contoh umum, dan kesulitan dalam notasinotasi dan istilah-istilah lainnya yang ada dalam matematika.

\section{APOS (Action, Processes, Object, and Schema)}

[4] menjelaskan konsep dari APOS (Action, Processes, Object, and Schema)

\section{Action}

- Membangun sebuah formula dari sebuah permasalahan eksternal.

- Mengevaluasi formula tersebut dengan memperhitungkan hal itu.

\section{Process}

- Kegiatan (action) yang dilakukan secara berulang-ulang, dari proses inilah dapat munculnya sebuah pemahaman atau pengetahuan (knowledge) terhadap apa yang sudah mereka lakukan.

\section{Object}

- Tahapan dimana seseorang dapat lanjut ke tingkat yang lebih tinggi, dikarenakan pengetahuan yang sudah mereka miliki sebelumnya.

\section{Schema}

- Tahapan dimana seseorang dapat menghubungkan permasalahan matematika yang satu dengan permasalahan matematika lainnya yang berkaitan dengan Action, Processes, dan Object yang sudah terkonstruksi.

\section{Metode Penelitian}

Jenis penelitian ini merupakan penelitian deskriptif kualitatif yang bertujuan mendeskripsikan kemampuan pemecahan masalah siswa dalam menyelesaikan masalah aljabar berdasarkan teori APOS (Action, process, object, schema). Instrumen yang digunakan dalam penelitian ini yaitu, soal tes pemecah masalah . Kemudian instrumen untuk mengetahui 
kemampuan pemecahan masalah matematika siswa menggunakan sebuah soal uraian materi aljabar, untuk memperkuat dan memperjelas jawaban, menggunakan pedoman wawancara yang berisi garis besar pertanyaan tentang bagaimana penyelesaian soal yang ia kerjakan. Metode pengumpulan data dilakukan dengan soal tes pemecahan masalah. Selanjutnya akan dipilih satu jawaban siswa sebagai sampel dari semua siswa yang terpilih untuk diikutsertakan dalam penelitian dengan jawaban yang tepat dari hasil tes pemecahan masalah untuk mengikuti tahap wawancara.

Prosedur penelitian ini diawali dengan kegiatan pendahuluan yaitu menentukan subjek penelitian. Subjek penelitian ini mengambil beberapa siswa dari SD Negeri 060911 kelas VI-A, karena pengalaman peneliti dalam melakukan kegiatan mengajar terbimbing. Kemudian melakukan penyusunan instrumen yang akan digunakan dalam mengukur variabel dalam penelitian ini.

Tes pemecahan masalah berupa sebuah soal uraian tentang aljabar guna memperoleh data tentang kemampuan memecahkan masalah. Kemudian dilakukan wawancara dengan menguraikan penjelasan tentang penyelesaian soal yang siswa kerjakan. Berikut adalah soal tes pemecahan masalah yang digunakan dalam penelitian ini :

Soal :

Ada sebuah pernyataan : $2 x+4 y=6$

Tentukan :

a. Jika pernyataan diatas ditambahkan dengan $7 x+6 y=10$

b. Variabel, koefisien, konstanta dari hasil nilai a

\section{Hasil Penelitian dan Pembahasan}

Hasil analisis soal tes pemecah masalah mengenai aljabar, beberapa siswa yang diikutsertakan dalam penelitian adalah sebagai berikut : 


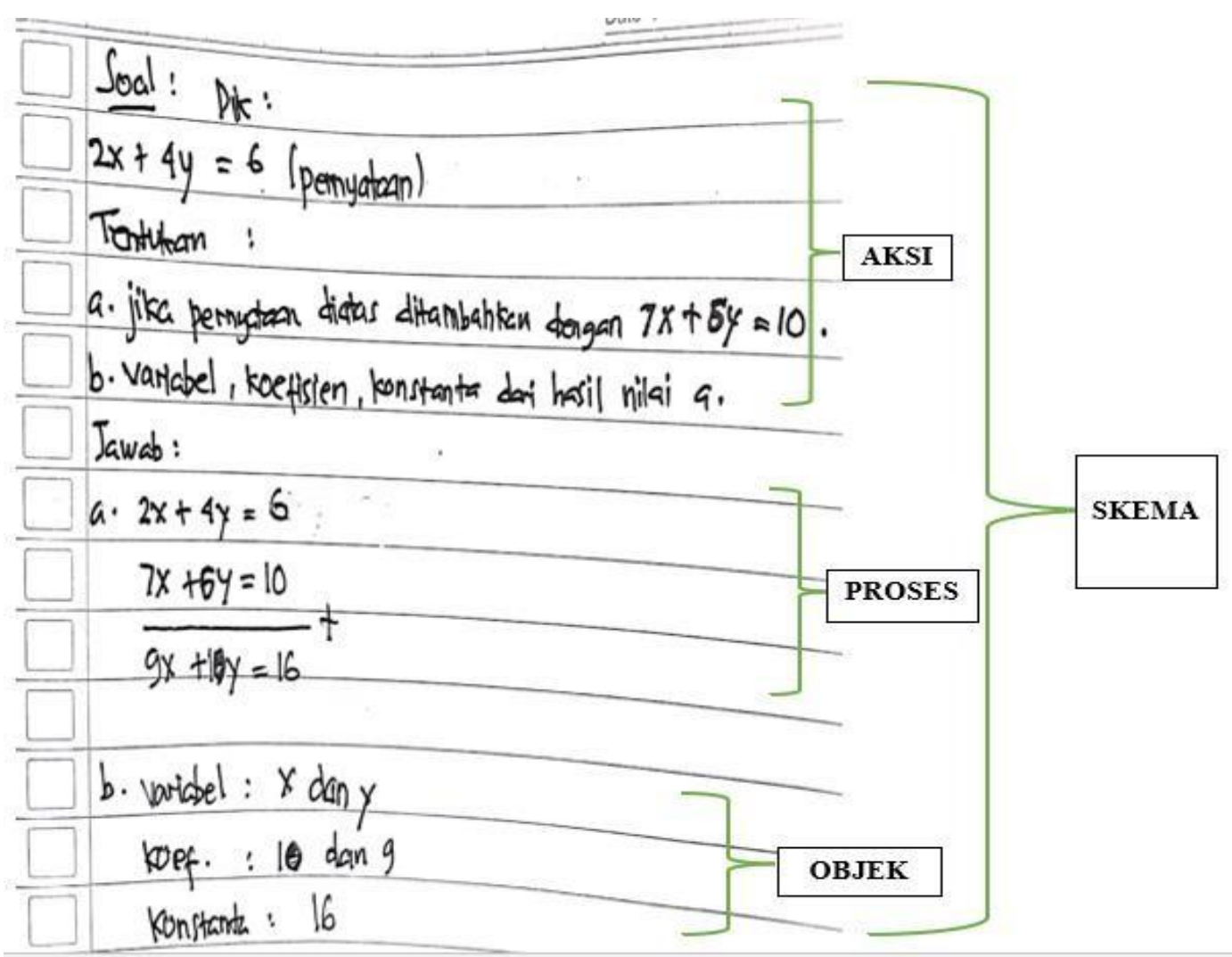

Berdasarkan hasil pengerjaan salah seorang dari beberapa siswa yang memiliki jawaban yang sama, pada tahap aksi siswa dapat memberikan jawaban dengan benar. Pada tahap proses siswa menjawab dengan benar terkait dengan penggunaan sistem persamaan yang diberikan. Pada tahap obejek, siswa mampu menentukan mana yang merupakan variabel, koefisien, dan juga konstanta. Pada tahap skema, siswa dapat menghubungkan permasalahan matematika yang satu dengan yang lainnya yang berkaitan dengan aksi, proses dan juga objek.

Dalam menyelesaikan masalah, bisa dilihat dalam wawancara, semua siswa yang terpilih untuk diikutsertakan dalam penelitian memiliki antusias yang sangat besar dan mereka aktif memberikan jawaban untuk sebuah soal yang sudah disediakan. Mereka memberikan tanggapan juga bahwasanya mereka mereka dapat dengan mudah memahami soal yang diberikan sehingga mampu memperoleh jawaban yang tepat pula.

\section{E. Kesimpulan}

Berdasarkan hasil penelitian maka diperoleh kesimpulan yaitu : Pada proses merumuskan, subjek menyebutkan informasi-informasi penting dalam soal, bagaimana menyelesaikannya dan apa yang diketahui dan ditanyakan dalam soal. Subjek juga mampu menjawab soal yang diberikan dengan tepat dan terstruktur baik itu dalam tahap aksi, proses, 
objek maupun skema. Selain itu, pembelajaran dengan teori APOS ini memiliki tingkat pengaruh yang besar terhadap kemampuan pemecahan masalah siswa SD. 


\section{Daftar Pustaka}

[1] Agoestanto A, Sukestiyarno Y.L, Isnarto, Rochmad, Lestari M.D. "The Position and Causes of Students Errors in Algebraic Thinking Based on Cognitive Style". International Journal of Instruction 12 (2019), 1431-1444.

[2] Anam M.K, Suharto, Murtikusuma R.P, Hobri, Oktavianingtyas E. 2018. ANALISIS KEMAMPUAN PEMECAHAN MASALAH MATEMATIKA SISWA BERDASARKAN TEORI APOS (ACTION, PROCESS, OBJECT, SCHEMA) DITINJAU DARI TIPE KEPRIBADIAN FLORENCE LITTAUER. Jurnal Kardikma. Vol 9 (2): 49-58.

[3] Arnawa M, Sumarno U, Kartasasmita B, and Baskoro E.T, "APPLYING THE APOS THEORY TO IMPROVE STUDENTS ABILITY TO PROVE IN ELEMENTARY ABSTRACT ALGEBRA", JOURNAL OF THE INDONESIAN MATHEMATICAL SOCIETY 13 (2007), 133-148.

[4] Asiala M, Brown A, DeVries D J, Dubinsky E, Mathews D, and Thomas K , "A Framework for Research and Curriculum Development in Undergraduate Mathematics Education". Research in Collegiate Mathematics Education (1997), 21-23.

[5] Gibson, J. (2014). Why Learn Algebra?. Retrieved from http://www. mathgoodies.com/articles/ why_learn_algebra.html.

[6] Moore R.C, "Making the transition to formal proof", Educational Studies in Mathematics 27 (1994), 249-266.

[7] Polya, G. 1973. How To Solve It, A New Aspect of Mathematical Method. New Jersey: Princenton University Press.

[8] Rudyanto E, Marsigit, and Wangid M.N. "The Use of Bring Your Own Device-based Learning to Measure Student Algebraic Thinking Ability". International Journal of Emerging Technologies in Learning. Vol 14. 23. 2019: 233-241

[9] Suwanto F.R, Aprisal, Misnasanti, Putra W.D.P, Sari R.H.Y. "APOS Theory towards Algebraic Thinking Skill'.Ahmad Dahlan International Conference on Mathematics and Mathematics Education (2017), 52-58.

[10] Tatang, H. 2000. Strategi Pemecahan Masalah (Problem-Solving) dalam Pembelajaran Matematika. UPI Bandung. 